\title{
Tordic Dog Whistles. Analyzing Discriminatory Discourses in the Parlance of the Scandinavian Radical Right Parties
}

\section{Luiza-Maria Filimon}

Postdoctoral Researcher, National School of Political and Administrative Studies (SNSPA), E-mail: luiza.filimon@gmail.com

\begin{abstract}
The Nordic states had an active radical right presence long before the economic and refugee crises that swept the shores of the European Union (EU) left in their wake a reinvigorated right-wing contingent. The radical right parties (RRPs) have not only registered various degrees of electoral success, but have also made inroads into the political mainstream. The three defining characteristics that set these parties apart from the more traditional far-right ones are: 1) the repudiation of hardcore extremism; 2) the search for political viability; and 3) the acquisition of mainstream recognition. The present article argues that as these parties compete for legitimacy, they are forced to alter their discriminatory rhetoric by switching tonal registers. One of the political strategies that enables them to put the outright "overt" in the "covert" is the recourse to dog whistle politics. How well can they overcome the stigma associated with their more extreme reflexes depends on a case by case basis. This article examines whether the four most prominent examples of Nordic radicalism (the Danish People's Party, Finns Party, Sweden Democrats, and Norway's Progress Party) have integrated dog whistles in their political messaging and tracks how these coded appeals change from one country to another. In analyzing the response to the 2015 refugee crisis, the study finds that to a certain extent,

\section{Rezumat}

In statele nordice, partidele radicale de dreapta aveau o prezență activă cu mult înainte ca ţărmurile Uniunii Europene (UE) să fie atinse de criza economică sau de cea a refugiaților - crize care au lăsat în urma lor un contingent revigorat al reacționarilor de dreapta. Astfel în ultimii ani am putut obseva cum partidele radicale de dreapta nu numai că au înregistrat o serie de succese electorale, dar aceste succese au fost dublate in anumite cazuri şi de incursiuni în mainstream-ul politic. Cele trei caracteristici definitorii care deosebesc aceste partide de cele tradiţionale de extremă dreapta sunt: 1) respingerea extremismului dur; 2) căutarea viabilității politice; şi 3) obținerea recunoașterii publice din partea unor partide de la centrul spectrului politic. Prezentul articol pleacă de la premisa că pe măsură ce aceste partide concurează pentru legitimitate și sunt nevoite să-şi modifice retorica discriminatorie prin schimbarea registrelor tonale. Recursul la dog whistles (ro.: fluier pentru câini) reprezintă o modalitate care le permite să mascheze excesele discriminatorii. Dacă aceste partide pot depăşi stigmatul asociat cu reflexele lor mai extreme depinde de la caz la caz. Acest articol examinează dacă cele patru partide radicale de dreapta din Peninsula Scandinavă (Partidul Popular Danez, Adevăraţii Finlandezi, Democraţii Suedezi şi Partidul Progresului din Norvegia) au integrat aceste dog whistle-uri în mesajele lor politice, urmărind totodată modul în care aceste apeluri codate se schimbă de la o țară la alta. Analizând răspunsul la criza refugiaților din
\end{abstract}


the rhetoric utilized falls into the coded register or at the very least purposefully attempts to veer away from the radical excesses which are marginalizing and self-exclusionary.
2015, s-a putut observa că aceste partide operează cu un registru codat sau că încearcă să evite excesele retorice radicale care produc efecte alienante și marginalizante.

Keywords: radical right parties, Nordic radicalism, racism, dog whistle politics, stereotypes, refugee crisis

\section{BY-SA License (https://creativecommons.org/licenses/by-sa/2.0)}

An earlier version of this paper has been presented at the Tenth Annual International Conference on Nordic and Baltic Studies "Dissent Versus Conformism in the Nordic, Baltic and Black Sea Areas", hosted by the Romanian Association for Baltic and Nordic Studies and the "Ovidius" University, Constanta, Romania, June 6-8, 2019.

This paper was financially supported by the Human Capital Operational Program 2014-2020, co-financed by the European Social Fund, under the project POCU/380/6/13/124708 no. 37141/23.05.2019, with the title "Researcher-Entrepreneur on the Labour Market in the Fields of Intelligent Specialization (CERT-ANTREP)", coordinated by the National University of Political Studies and Public Administration.

\section{Introduction}

The decade following the economic recession has been characterized by the ascent of a reactionary backlash of right wing inspiration that has manifested itself in various shapes and sizes. There are the regular suspects like Marine Le Pen's Front National that now goes by Rassemblement National or Geert Wilders' Party for Freedom, the newcomers like Alternative für Deutschland or the Spanish Vox, the eastern illiberals of hybrid provenance like the Hungarian ruling party Fidesz or Poland's Law and Order, etc. They share different pet-peeves: the loss of sovereignty, Euroscepticism, or an anti-minorities and anti-immigration animus, etc. Though these parties may display an illiberal ethos, they are not outright extremist: unlike some neo-fascist incarnations that are outlawed or at the very least cast away to the outer edges of the political spectrum, they do not seek to overthrow the democratic order, instead they attempt to disrupt the system from within through cooption so that they can advance their agenda and reform it in accordance to their vision ${ }^{1}$. Yet there can be no disruption if the pathways towards political legitimacy are closed off especially on the electoral front.

1 See: Mihaela Ivănescu and Luiza-Maria Filimon, "Mainstream Fringes or Fringe Mainstream? An Assessment of Radical Right (Re) Alignments in the European Parliament after the 2014 and 2019 Elections", European Review, 2020, https://doi.org/10.1017/S1062798720000976. Originally articulated by Cass Mudde in The Ideology of the Extreme Right (Manchester: Manchester University Press, 2000), this categorization distinguishes between extremist and radical parties. 
An openly discriminatory rhetoric might breed fidelity among some segments of the electorate, but it hardly suffices in terms of mainstream competiveness. Instead, this rhetoric ensures that such parties will be labeled as racist, nationalist, extremist, xenophobic and the list of "phobics" could continue.

In the case of the Scandinavian Peninsula, radical right parties (RRPs) such as the Danish People's Party, Finns Party, Swedish Democrats or the Norwegian Progress Party have been a staple of the political landscape long before the turmoil of the recent years, and, more importantly, they were never on the brink of extinction as was the case with some of their European counterparts. Instead, the more time passed, the more viable they became, some more than others. The contemporary crises only made them more relevant to the point that they flirted with the mainstream and were not dismissed or shunned out of hand ${ }^{2}$. If the goal of any party is to be in power or at least adjacent to power, then these "outsider" parties constitute an interesting case-study. The present article is interested in analyzing how and to what degree the rhetoric of these parties has evolved over time - mutating from the more stereotypical nationalist creeds to something that can be passed for something else, that can be disguised and shrouded in a deceptive layer of common sense, something that can resonate with the general electorate. This "something" is commonly known as a "dog whistle".

Primarily associated with the American political and electoral scene, dog whistles are not an isolated phenomenon; they have also been used anywhere from the United Kingdom, Canada, Australia, France, India, etc. Dog whistles are a form of racialized coded messaging that are designed to be inconspicuous - at the first glance, they do not raise any flags where the

\footnotetext{
2 On the issue of mainstreaming see: Eviane Leidig (ed.), Mainstreaming the Global Radical Right (CARR Yearbook 2019/2020) (Stuttgart and Hannover: ibidem Press, 2020); Tjitske Akkerman, Sarah L de Lange, and Matthijs Roodujin (eds.), Radical Right-Wing Populist Parties in Western Europe. Into the Mainstream? (Oxon and New York: Routledge, 2016); Pontus Odmalm and Eve Hepburn (eds.), The European Mainstream and the Populist Radical Right (Oxon and New York: Routledge, 2017); Aristotle Kallis, "The Radical Right in Contemporary Europe", SETA - Foundation for Political, Economic and Social Research, no. 13 (December 2014), https://file.setav.org/Files/Pdf/20150102163845_the-radical-right-incontemporary-europe-pdf.pdf,
} 
general electorate is concerned, yet intrinsically they signal something that resonates with particular subgroups. While mainstream parties are also known to employ dog whistles (see the case of the Republican Party in the United States), RRPs appeal to this rhetoric in order to sway to their side voters who might otherwise not resonate with them.

The issue transforms from one where the Other - the immigrant, the refugee, the asylum seeker - is hated for the color of their skin, their belief system, their language, their customs and practices, into one that is strictly about the economy or security. A country's resources are limited, the welfare system can only manage so many beneficiaries ergo the Other is a burden and selfish at that since the Other does not care about these issues and only wants to take what is not even rightfully theirs. This is essentially what a dog whistle looks like. It diverts the focus from the racial component and obfuscates the discriminatory sentiments. In political communication, dog whistles are understood as words that may appear to some as innocuous and non-injurious, but which signal to segments of the electorate what Ian Olasov describes as "a covert appeal to some noxious set of views" that falls outside "the [general] audience's conscious awareness" 3 .

In order to assess whether the Nordic RRPs owe some of their success not to an ideological change of heart but to a clever rhetorical makeover, the article will look into several issues:

1) "what are dog whistles?": where does the openly racist rhetoric end and the dog whistles begin (or vice-versa)?;

2) "Scandinavian right-wing radicalism": what is the ideological makeup of the Nordic RRPs?;

3) "the mainstreaming of the radical-right": what was the gateway into the mainstream? Did the RRPs became less radical or did the centrist party gravitate towards more radical positions?;

4) “Nordic dog whistles": instances and occurrences.

\footnotetext{
${ }^{3}$ Ian Olasov, "Offensive political dog whistles: you know them when you hear them. Or do you?", Vox, 07.11.2016, https://www.vox.com/the-big-idea/2016/11/7/13549154/dog whistles-campaign-racism.
} 
For the purpose of the present analysis, we will briefly look into how the rhetorical registers were created and operated with by the representatives of these parties during the 2015-2016 refugee crisis.

\section{Theoretical Framework}

According to Bethany L. Albertson, "dog whistles" represent a form of communication known as "multivocal communication" 4 . In so far as they have proven to be effective, the author argues that these multivocal appeals or dog whistles work "because [they] target[...] those predisposed to respond favorably to the message and go[...] over the heads of those who might be turned off by it" ${ }^{\prime \prime}$. These groups - those influenced and those unaffected - are not that strictly delimitated. Furthermore, dog whistles are highly versatile: they can be tweaked, amended, improved, redirected in order to target the appropriate audience and induce the expected reaction. In other words, no one is immune to them, but depending on their degree of sophistication, one can pick up on them and recognize them for what they are.

When it comes to the racialized dog whistles that make the object of the present discussion, we have to understand that they operate at the intersection of two dispositions. Per Tali Mendelberg, in the United States, at one level, we find the "Norm of Racial Egalitarianism" - here, all "outright expressions of racism [are deemed] unacceptable" 6 . This is why when faced with such displays, the immediate reaction is to recoil, to sanction and castigate those that invoke this rhetoric. Though President Trump combines the "overt" register with the "coded" one, for the most part, he did away with the code, appealing to the baser instincts and bringing them to the surface. A pure manifestation of the Id. At the other

\footnotetext{
4 Bethany L. Albertson, “Dog whistle Politics: Multivocal Communication and Religious Appeals", Political Behavior 41, 1117 (December 2019), https://doi.org/10.1007/s11109-01909568-3.

5 Ibid., 2.

${ }^{6}$ See Tali Mendelberg, The Race Card. Campaign Strategy, Implicit Messages and the Norm of Equality (Princeton and Oxford: Princeton University Press, 2001 ) referred to in Jennifer Saul, "Donald Trump, Racial Figleaves, and the Breadth of Bigotry", Huffington Post, 21.01.2016, https://www.huffpost.com/entry/donald-trump-racialfigle_b_9033224?guccounter=1.
} 
level, people, especially white people, are likely to be predisposed to "racial resentment": beneath the polite surface, this resentment tends to go "unacknowledged and unarticulated"7, smoldering until the right combination of words triggers it and legitimates it in some fashion or another. Jennifer Saul, Professor of Psychology at the University of Sheffield, explains how the dog whistles target this level: "by talking about 'the culture of the inner city' or 'welfare' a politician may avoid mentioning race, while still causing voters to bring their racial resentment to bear on their voting decisions" ${ }^{\prime \prime}$.

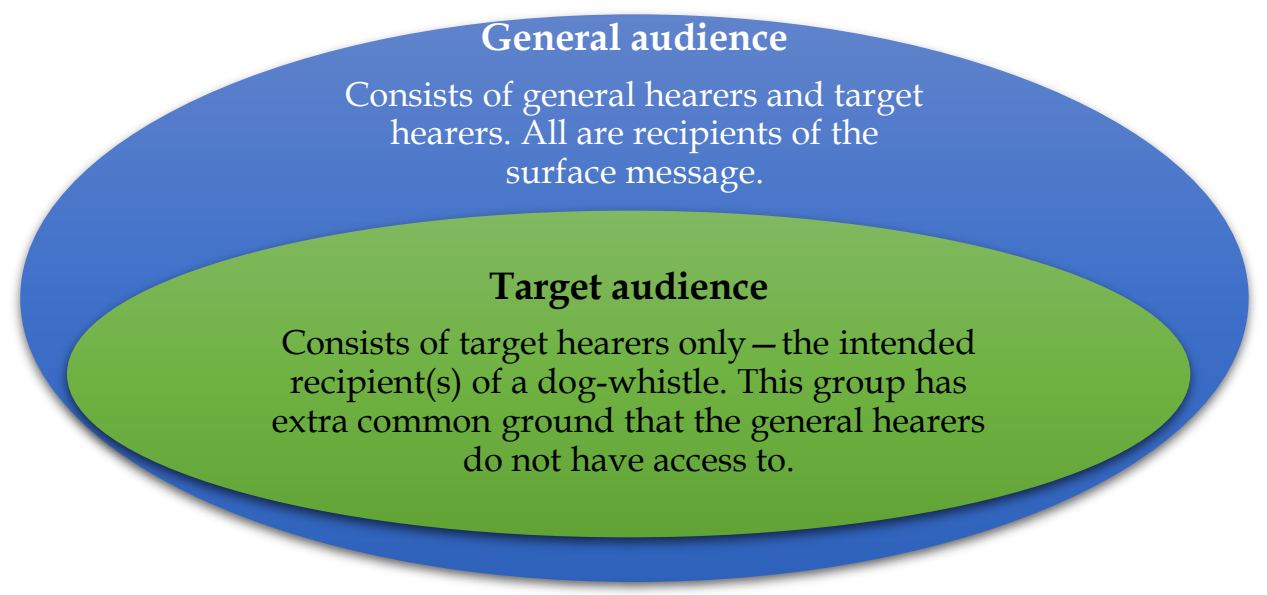

Figure 1: Message Alignment with Audience

Source: Kimberly Witten, “Dogwhistle Politics: the New Pitch of an Old Narrative", San Francisco University, Spring 2008, 5, https://www.academia.edu/42929858/Dogwhistle Politics the New Pitch of an Old Narrative

Where the United Stated is concerned, by the time the syntagm "dog whistle" was first used, the coded appeals had already been employed as a discursive strategy for quite some time. Unrelated to the political practice, in 1988, Richard Morin - a pollster for The Washington Post - remarked how opinion polls could be influenced by what he referred

\footnotetext{
7 Ibid.

8 Saul, “Donald Trump, Racial Figleaves....".
} 
to as the "dog whistle effect". Specifically, he noted that changes in the wording - however brief - could have a significant impact on the respondents: "[they] hear something in the question that researchers do not" ${ }^{\prime \prime}$. Long before Morin arrived at this conclusion, political operatives had already recognized the undeniable underhanded appeal that certain wordings could have on certain people and how, in turn, this could allow them to pursue various kinds of punitive policy measures

In light of this, at a definitional level, the dog whistles represent a form of coded communication premised on a racialized imagery which politicians frequently use deliberately in order to manipulate and assuage certain key-audiences while seeming unremarkable to the wider public / audience (see Figure 1). At the linguistic level, Kimberly Witten defines the dog whistle as:

"a speech act designed, with intent, to allow two plausible interpretations, with one interpretation being a private, coded message targeted for a subset of the general audience, and concealed in such a way that this general audience is unaware of the existence of the second, coded interpretation" ${ }^{10}$.

\section{An American Affair: An Overview of Dog Whistle Politics}

In the US, dog whistle politics have been a prominent electoral strategy that has originated with the Republican Party and was later also adopted by the Democratic Party whenever they were deemed to be a viable electoral strategy. It is not a coincidence that when the Democratic Party made use of dog whistles like during Bill Clinton's first presidential

\footnotetext{
${ }_{9}$ Morin quoted in Jennifer Saul, "Dog whistles, Political Manipulation and Philosophy of Language", in New Work on Speech Acts, ed. Daniel Fogal, Daniel W. Harris, and Matt Moss (Oxford: Oxford University Press, 2018), 361. In this article, the source is quoted from Prashanth Bhat and Ofra Klein, "Covert Hate Speech: White Nationalists and Dog Whistle Communication on Twitter", in Twitter, the Public Sphere, and the Chaos of Online Deliberation, ed. Gwen Bouvier and Judith E. Rosenbaum (Cham, Switzerland: Palgrave Macmillan, 2020), 153.

10 Kimberly Witten, "Dogwhistle Politics: the New Pitch of an Old Narrative", San Francisco University, Spring 2008, 2, https:// www.academia.edu/42929858/Dogwhistle_Politics_the_New_Pitch_of_an_Old_Na rrative. Also quoted in Saul, “Dog whistles, Political Manipulation”, 362.
} 
bid, it succeeded in emulating the success of their Republican counterparts. In Dog Whistle Politics: How Coded Racial Appeals Have Reinvented Racism and Wrecked the Middle Class, Ian Haney-López explains how:

“[i]n the last 50 years, dog whistle politics has driven broad swaths of white voters to adopt a self-defeating hostility toward government, and in the process has remade the very nature of race and racism. American politics today [he says] [...] cannot be understood without recognizing racism's evolution and the power of pernicious demagoguery"11.

Based on Haney-López's theorization, Grossman points out that "[t]he basic mechanism" at play in the dissemination of dog whistles is quite "simple": "call upon the anxiety or fear of minorities that already resides not-so-far beneath the surface, divide class interests, and win elections"12. In attempting to win elections, the instrumentalization of dog whistles has been streamlined and has involved stoking pre-existent antiminority or anti-immigrant fears. Not surprisingly, some of the more prominent dog whistles are centered on the appeal to law and order, tough on crime attitudes, security and terrorism, or perceived welfare abuses. After all, "some groups commit more crimes and use more welfare, other groups are mainly unskilled and illiterate illegals, and some religions inspire violence and don't value human life"13.

The underlying mechanics behind the dog whistles were deconstructed by Lee Atwater, a Republican political consultant and strategist in an interview from 1981 where he recounted the evolutionary forces to which a racist ethos and practices had been subjected over time. As the tale goes, initially, overt racist appeals were acceptable ("You start out in 1954 by saying, the "N-word, n-word, n-word."), but at some point, something changes ("By 1968 you can't say the "n-word" - that hurts you.

\footnotetext{
11 Ian Haney-López, Dog Whistle Politics: How Coded Racial Appeals Have Reinvented Racism and Wrecked the Middle Class (Oxford: Oxford University Press, 2014), ix.

12 Sara Grossman, "Blog: Revisiting 'Dog Whistle Politics'”, Othering \& Belonging Institute, https:// belonging.berkeley.edu/blog-revisiting-dog whistle-politics.

${ }_{13}$ Haney Lopez, Dog Whistle Politics, 3-4.
} 
Backfires") and the backlash triggers a readjustment ("So you say stuff like forced busing, states' rights and all that stuff. You're getting so abstract now, you're talking about cutting taxes, and all these things you're talking about are totally economic things") that just so happens to disproportionately affect the blacks ("a by-product of them is, blacks get hurt worse than whites"). The end result: an "abstract" and "coded" rhetoric that completely erases the racial component from the equation ("we are doing away with the racial problem one way or the other. [...] sitting around saying, "We want to cut taxes and we want to cut this," is much more abstract [...] and a hell of a lot more abstract than [the nword]" $)^{14}$.

It would be one thing if dog whistles were part of the toolbox of a certain party, but their rather accessible mechanics makes them appealing to all sorts of parties. They are noxious precisely because they are not isolated to a single party, instead they can be utilized by a multitude of political actors and can be framed under the parameters of a legitimate debate. The recourse to coded appeals does not need to come from a racist mindset, it can just be a crude and cynical means to an end or what Haney López refers to as the desire "to manipulate racial animus in pursuit of power" ${ }^{\prime \prime}$.

Dog whistles are more than just a rhetoric device, they reshape, reframe, recode, rewrite the terms of the debate so that the exploited becomes the exploiter taking advantage of a system that was never meant to serve them in the first place. In light of this, a blueprint emerges: assure yourself of the fidelity of a target audience -> win elections -> make policy changes that disadvantage particular groups but that are worded in a desensitized manner $->$ rinse and repeat. Based on the American model, we can look in other places and see whether we can find these coded tropes,

\footnotetext{
14 Lee Atwater interviewed in 1981 quoted in Haney López, Dog Whistle Politics, 57. For the full interview, see: Rick Perlstein, “Exclusive: Lee Atwater's Infamous 1981 Interview on the Southern Strategy", The Nation, 13.11.2012, https://www.thenation.com/article/archive/exclusive-lee-atwaters-infamous-1981interview-southern-strategy/.

15 Ibid., 113.
} 
see who is using them primarily, who else might be using them and assess the normative implications at the policy level.

\section{A Scandinavian Tale: Radicalism, Radicalization and the} Mainstreaming Connection

\section{Act 1: The Protagonists}

In the case of the Nordic countries, Anders Widfeldt remarks that for a long time, they used to be divided into two categories: in Denmark and Norway, the RRPs were "relatively strong", while in Finland and Sweden, they were not as effective ${ }^{16}$. In Denmark, the Dansk Folkeparti Danish People Party had a presence in the Folketinget - the Danish Parliament - ever since its inception: in the 1998 elections, it garnered a quarter-million votes and 13 seats. Since then, its voting share continued to grow incrementally, providing parliamentary support as a result of three out of the following four general elections. In 2015, the Danish People's Party received almost triple the amount of votes obtained in 1998. Over 740.000 Danes or the equivalent of $20 \%$ of the citizens inscribed on the voting lists voted for the party and once again, it found itself in the position to provide parliamentary support (see Table no. 1).

\begin{tabular}{|c|c|c|c|c|c|c|}
\hline Year & $\begin{array}{c}\text { No. of } \\
\text { votes }\end{array}$ & $\begin{array}{c}\text { Vote } \\
\text { share }\end{array}$ & Position & $\begin{array}{c}\text { Seats } \\
\text { won }\end{array}$ & $\begin{array}{c}\text { Gained } \\
\text { Lost } \\
\text { Seats }\end{array}$ & $\begin{array}{c}\text { Relation } \\
\text { towards } \\
\text { Government }\end{array}$ \\
\hline 1998 & 252,429 & $7.4 \%$ & V & $13 / 179$ & - & in opposition \\
\hline 2001 & 413,987 & $12.0 \%$ & III & $22 / 179$ & +9 & $\begin{array}{c}\text { provides } \\
\text { parliamentary } \\
\text { support }\end{array}$ \\
\hline 2005 & 444,205 & $13.3 \%$ & III & $24 / 179$ & +2 & $\begin{array}{c}\text { provides } \\
\text { parliamentary } \\
\text { support }\end{array}$ \\
\hline 2007 & 479,532 & $13.9 \%$ & III & $25 / 179$ & +1 & provides \\
\hline
\end{tabular}

\footnotetext{
16 Anders Widfeldt, "The Radical Right in the Nordic Countries", in The Oxford Handbook of the Radical Right, ed. Jens Rydgren (Oxford: Oxford University Press, 2018), 545.
} 


\begin{tabular}{|c|c|c|c|c|c|c|}
\hline & & & & & $\begin{array}{c}\text { parliamentary } \\
\text { support }\end{array}$ \\
\hline 2011 & 436,726 & $12.3 \%$ & III & $22 / 179$ & +3 & in opposition \\
\hline $\mathbf{2 0 1 5}$ & $\mathbf{7 4 1 , 5 3 9}$ & $\mathbf{2 1 . 1} \%$ & II & $37 / 179$ & $\mathbf{+ 1 5}$ & $\begin{array}{c}\text { provides } \\
\text { parliamentary } \\
\text { support }\end{array}$ \\
\hline $\mathbf{2 0 1 9}$ & 308,513 & $\mathbf{8 . 7} \%$ & III & $16 / 179$ & -21 & in opposition \\
\hline
\end{tabular}

Table no. 1: Danish People Party's Results over Seven Electoral Cycles Source: Statistics Denmark, "Elections to the Folketing", https://www.dst.dk/en/Statistik/emner/befolkning-ogvalg/valg/folketingsvalg.

In the Norwegian case, the oldest of its counterparts, the Fremskrittspartiet - the Progress Party - was established in 1973 and is considered the third largest party in the country. While turnout for this party has ebbed and flowed throughout the decades, ever since the 1997 general elections, it never dipped below 350.000 voters. In the 2005 and 2009 elections, it garnered near or more than 600.000 votes - the equivalent of over $20 \%$ of the voting share. In the subsequent 2013 and 2017 elections, support for it dropped by more than five percentage points though the drop did not deter it from becoming on both occasions, a member of the coalition government. When the Progress Party left the government in January 2020, it was not because it was pushed out by the other coalition members, but because of the Conservative Prime-Minister Erna Solberg's decision to repatriate a woman and her children back to Norway - the woman allegedly had ties to the Islamic State. The story is known as the “jihadist-wife row"17 (see Table no. 2).

\begin{tabular}{|c|c|c|c|c|c|c|}
\hline Year & $\begin{array}{c}\text { No. of } \\
\text { votes }\end{array}$ & $\begin{array}{c}\text { Vote } \\
\text { share }\end{array}$ & Position & $\begin{array}{c}\text { Seats } \\
\text { won }\end{array}$ & $\begin{array}{c}\text { Gained } \\
/ \\
\text { Lost } \\
\text { Seats }\end{array}$ & $\begin{array}{c}\text { Relation } \\
\text { towards } \\
\text { Government }\end{array}$ \\
\hline 1997 & 395,376 & $15.3 \%$ & II & $25 / 169$ & +15 & in opposition \\
\hline
\end{tabular}

$17 * * *$, "Norway party quits government in 'jihadist-wife' row", BBC News, 20.01.2020, https://www.bbc.com/news/world-europe-51174550. 


\begin{tabular}{|l|l|c|c|c|c|c|}
\hline 2001 & 369,236 & $14.6 \%$ & III & $26 / 169$ & +1 & in opposition \\
\hline 2005 & 582,284 & $22.1 \%$ & II & $38 / 169$ & +12 & in opposition \\
\hline $\mathbf{2 0 0 9}$ & $\mathbf{6 1 4 , 7 2 4}$ & $\mathbf{2 2 . 9 \%}$ & II & $\mathbf{4 1 / 1 6 9}$ & +3 & in opposition \\
\hline 2013 & 463,560 & $16.3 \%$ & III & $29 / 169$ & -12 & in government \\
\hline 2017 & 444,423 & $15.3 \%$ & III & $27 / 169$ & -2 & in government \\
\hline
\end{tabular}

Table no. 2: Progress Party's Results over Six Electoral Cycles

Source: Statistics Norway, "Elections: General elections", https://www.ssb.no/en/valg?de=General+elections.

Where the other two were concerned, the growth registered by them was significant in how abrupt and persistent it was. In Finland, the Perussuomalaiset - Finns Party jumped from five seats in the Parliament after the 2007 elections to 39 seats in 2011, when it obtained over half a million votes - five times the amount it received in 2007 . With nearly $20 \%$ of the voting share, it also jumped five positions in party standings: from occupying the eighth place in the 2007 and 2011 elections, it became the third largest party. This position further improved in the subsequent two elections, where despite very low dips in support around the margin of one percentage point, it became the second largest party in the country. After the 2015 elections, it also became for a brief period of time - 2015-2017 - a member of the right-wing government coalition, along with the liberalconservative Centre Party and the centre-right and conservative National Coalition Party - namely the first and third largest parties in Finland at that time (see Table no. 3). .

\begin{tabular}{|c|c|c|c|c|c|c|}
\hline Year & $\begin{array}{c}\text { No. of } \\
\text { votes }\end{array}$ & $\begin{array}{c}\text { Vote } \\
\text { share }\end{array}$ & Position & $\begin{array}{c}\text { Seats } \\
\text { won }\end{array}$ & $\begin{array}{c}\text { Gained } \\
\text { Lost } \\
\text { Seats }\end{array}$ & $\begin{array}{c}\text { Relation towards } \\
\text { Government }\end{array}$ \\
\hline 1999 & 26,440 & $0.99 \%$ & IX & $1 / 200$ & - & in opposition \\
\hline 2003 & 43,816 & $1.57 \%$ & VIII & $3 / 200$ & +2 & in opposition \\
\hline 2007 & 112,256 & $4.05 \%$ & VIII & $5 / 200$ & +2 & in opposition \\
\hline $\mathbf{2 0 1 1}$ & $\mathbf{5 6 0 , 0 7 5}$ & $\begin{array}{c}\mathbf{1 9 . 0 5} \\
\%\end{array}$ & III & $\mathbf{3 9 /}$ & +34 & in opposition \\
& & & $\mathbf{2 0 0}$ & & \\
\hline
\end{tabular}




\begin{tabular}{|c|c|c|c|c|c|c|}
\hline 2015 & 524,054 & $\begin{array}{c}17.65 \\
\%\end{array}$ & II & $\begin{array}{c}38 / \\
200\end{array}$ & -1 & in government \\
\hline 2019 & 538,805 & $17.5 \%$ & II & $39 /$ & +1 & in opposition \\
& & & & 200 & & \\
\hline
\end{tabular}

Table no. 3: Finns Party's Results over Six Electoral Cycles

Source: Statistics Finland, "Parliamentary Elections",

https://www.stat.fi/til/evaa/index en.html.

Unlike in the Norwegian case, Finns Party was pushed out of the government after an internecine conflict split the party when an immigration hardliner, Jusso Halla-aho, became the new leader of the party. After hemorrhaging 20 members among which there were also those that happened to hold all the Finns Party's cabinet appointments, the party's stay in government came to an abrupt end ${ }^{18}$. The departing members went on to form another parliamentary group - Blue Reform the group will lose all the seats in the 2019 elections. Meanwhile, Finns Party gained one more member compared to 2015. As such it retained the same number of voters and voter share since it made the electoral jump from niche party (between 1999 and 2007) to a top three party, even top two if we go by the results obtained in 2015 and 2019.

\begin{tabular}{|c|c|c|c|c|c|c|}
\hline Year & $\begin{array}{c}\text { No. of } \\
\text { votes }\end{array}$ & $\begin{array}{c}\text { Vote } \\
\text { share }\end{array}$ & Position & $\begin{array}{c}\text { Seats } \\
\text { won }\end{array}$ & $\begin{array}{c}\text { Gained } \\
\text { / Lost } \\
\text { Seats }\end{array}$ & $\begin{array}{c}\text { Relation } \\
\text { towards } \\
\text { Government }\end{array}$ \\
\hline 1998 & $\mathbf{1 9 , 6 2 4}$ & $0.4 \%$ & VIII & $0 / 349$ & - & $\begin{array}{c}\text { not in the } \\
\text { parliament }\end{array}$ \\
\hline 2002 & 76,300 & $1.4 \%$ & VIII & $0 / 349$ & - & $\begin{array}{c}\text { not in the } \\
\text { parliament }\end{array}$ \\
\hline 2006 & 162,463 & $2.9 \%$ & VIII & $0 / 349$ & - & $\begin{array}{c}\text { not in the } \\
\text { parliament }\end{array}$ \\
\hline 2010 & 339,610 & $5.7 \%$ & VI & $20 / 349$ & $\mathbf{+ 2 0}$ & in opposition \\
\hline $\mathbf{2 0 1 4}$ & $\mathbf{8 0 1 , 1 7 8}$ & $12.9 \%$ & III & $\mathbf{4 9 / 3 4 9}$ & $\mathbf{+ 2 9}$ & in opposition \\
\hline
\end{tabular}

18 ***, "Finland's populist party has cracked in two", The Economist, 14.06.2017, https://www.economist.com/europe/2017/06/14/finlands-populist-party-has-cracked-intwo. 


\begin{tabular}{|l|l|l|l|l|l|l|}
\hline 2018 & $\mathbf{1 , 1 3 5 , 6 2 7}$ & $\mathbf{1 7 . 5} \%$ & III & $\mathbf{6 2} / 349$ & $\mathbf{+ 1 3}$ & in opposition \\
\hline
\end{tabular}

Table no. 4: Swedish Democrats' Results over Six Electoral Cycles

Source: Statistics Sweden, "General elections, results", https://www.scb.se/en/finding-statistics/statistics-by-subjectarea/democracy/general-elections/general-elections-results/.

Last but not least, in the Swedish case, the Sverigedemokraterna - the Swedish Democrats were an extra-parliamentary party until the 2010 elections. Founded in 1988, the second oldest party of the four analyzed, had enjoyed very little support on the part of the electorate. By its tenth year, it was still only receiving less than 20.000 votes - at best. For the next two election cycles, this trend started to change when its turnout improved significantly: it received more than 150.000 votes in the 2006 election even though it remained outside the confines of the parliament. The pattern further changed in 2010, when it more than doubled its support and gained 20 seats in the Riksdag. In the following two elections, the electoral scores continued to improve significantly. In 2014, it received over 800.000 votes and 49 seats in the Parliament while, in 2018, it garnered over one million votes and 62 seats. The voting share more than tripled compared to 2010 and the Swedish Democrats became the third largest party in the country for two electoral cycles consecutively. Notably, unlike in the previous cases, the Swedish Democrats remained the only party that has not been in government though, according to Widfeldt: "[i]n the longer term, [...] gradual acceptance of [Swedish Democrats] by at least some other Swedish parties is possible - even probable"19 (see Table no. 4).

\section{Act 2: The Context}

As mentioned in the beginning, in recent years we have witnessed a surge in right-wing radicalism that is only in part predicated on the typical radical right tropes one might come to expect: nativism, nationalism, racism, or reactionarism, etc. What stands out is the effort put by these

\footnotetext{
19 Anders Widfeldt, "The Growth of the Radical Right in Nordic Countries: Observations from the Past 20 Years", Migration Policy Institute, Washington DC, June 2018, 25, www.migrationpolicy.org.
} 
parties into distancing themselves from their less savory origins or from other more extremist parties. One region in which this effort has been executed with a rather high degree of success has been Northern Europe. Elisabeth Niklasson and Herdis Hølleland argue that the parliamentary breakthroughs registered by these parties have perturbed the traditional party coalitions and alliances, forcing "establishment parties to bend the political conversation around their specific issue areas" 20 .

The establishment parties have bent so far as to start incorporating the messages espoused by RRPs. For example, in the Danish elections from 2019, the surging Social Democrats and liberals adopted hardline positions on immigration that not too far ago had been "the preserve of the far right" $^{\prime 21}$. The Social Democrats' policy proposal on immigration contained provisions about "[deporting] asylum seekers to special reception centres outside Europe - such as North Africa - while their requests were processed", "a cap on the number of "non-Western" immigrants allowed into the country" 22 as well as "all immigrants [being] forced to work 37 hours a week in exchange for benefits" ${ }^{23}$. On the immigration issue, Mette Frederiksen, the leader of the Social Democrats is noted to have said that "75 percent of parliamentarians support a tough immigration policy"24. As a matter of fact, one of the "key reasons" attributed for the Danish People's Party loss of support among the constituents in the 2019 elections, had been "[t]he adoption of the vast majority of the [party]'s programme on

20 Elisabeth Niklasson and Herdis Hølleland, "The Scandinavian far-right and the new politicisation of heritage", Journal of Social Archaeology 18, no. 2 (June 2018): 122. See also: Henk van Houtum and Rodrigo Bueno Lacy, "The political extreme as the new normal: the cases of Brexit, the French state of emergency and Dutch Islamophobia", Fennia. International Journal of Geography 195, no. 1 (2017): 85-101, https://doi.org/10.11143/fennia.64568.

${ }^{21}$ Jon Henley, "Denmark's centre-left set to win election with anti-immigration shift", The Guardian, 04.06.2019, https://www.theguardian.com/world/2019/jun/04/denmark-centreleft-predicted-win-election-social-democrats-anti-immigration-policies.

$22 * * *$, "Mette Frederiksen: The new face of the Danish Social Democratic model", The Local, 04.06.2019, https://www.thelocal.dk/20190604/mette-frederiksen-the-new-face-of-thedanish-social-democratic-model.

${ }^{23}$ Richard Orange, "Mette Frederiksen: the anti-immigration left leader set to win power in Denmark", The Guardian, 11.05.2019, https://www.theguardian.com/world/2019/may/11/denmark-election-mattefrederiksen-leftwing-immigration. 24***, "Mette Frederiksen: The new face of the Danish Social Democratic model". 
immigration by the opposition Social Democrats" 25 . Overall, establishment politicians are adapting themselves to a certain animus present among the wider electorate. It is at this intersection between a radicalizing center and an inwardly-bent electorate that the RRPs have sought to re-envision themselves as "respectable radicals"26.

On the inclusion of RRPs into the mainstream, Tjitske Akkerman et al. argue that such a trend can be predicated on the "inclusion-moderation thesis" which states "that participation in democratic institutions and procedures will amend the radical nature and ideology of political parties"27. As the basis for this theorization, the authors cite Anthony Downs's median-voter theorem which states "that parties will appeal to the median voter in order to attract a majority of votes" 28 . Yet this hypothesis goes both ways, RRPs might moderate their more radical excesses, but, the mainstream parties will also pursue the path of least resistance where the voters are concerned. Moreover, we have seen in practice that if mainstream parties do not vacillate between radical and moderate positions and instead adopt a more hardline stance in terms of both rhetoric and policy direction, support for the more radical option can drop (as was seen in the Danish case, but as has also happened in other states, like in the Czech Republic).

The moderation argument can also be applied in the case of parties pursuing higher offices since "office is supposed to have a moderating effect" 29 . The general idea goes something along these lines: "[i]n coalition governments, policy and ideological distances that exist between coalition

\footnotetext{
${ }^{25}$ Michael Barrett, "Danish People's Party braces itself for tough election night", The Local, 04.06.2019, https://www.thelocal.dk/20190604/danish-peoples-party-braces-itself-fortough-election-night.

${ }_{26}$ Duncan McDonnell and Annika Werner, "Respectable radicals: why some radical right parties in the European Parliament forsake policy congruence", Journal of European Public Policy 25, no. 5 (2018): 747-763, https://doi.org/10.1080/13501763.2017.1298659.

27 Tjitske Akkerman, Sarah L de Lange, and Matthijs Roodujin, "Inclusion and mainstreaming? Radical right-wing populist parties in the new millennium", in Radical Right-Wing Populist Parties in Western Europe. Into the Mainstream?, ed. Tjitske Akkerman, Sarah L de Lange, and Matthijs Roodujin (Oxon and New York: Routledge, 2016), 3.

28 Ibid.

${ }^{29}$ Ibid., 4.
} 
partners have to be bridged" ${ }^{30}$. Here as well, we have to take into account the fact that the RRPs are not the only ones expected to compromise. Furthermore, the available empirical analyses on this topic have noted that RRPs do not need to "de-radicalize" in order to be accepted in governmental coalitions, nor do they shy from exhibiting "a radical profile while in office" ${ }^{\prime 31}$.

These figures highlight the fact that the radical presence is not just an electoral happenstance, but part of a wider radicalization trend. The presence of these parties in government also signals a propensity towards their normalization. As noted earlier, the policies pursued by them receive popular support which enables them in turn "to gain a number of seats in decision-making assemblies"32. Björn Fryklund points out how, ironically, the democratic process creates a rather problematic situation where "these parties establish themselves and in their policies and rhetoric advocate a society based on ethnic and cultural homogeneity" 33 .

The boomerang effect at the societal level is rather disconcerting: in having these parties set the tone of policy directions as it has been known to happen with immigration for example, minority groups particularly those of a foreign provenance can be "excluded from participating in society", can have "their freedom and rights limited", while at the same time, the "exclusion and inclusion mechanisms in society [are] strengthened"34. Furthermore, according to Viktoryia Schnose, "the probability of radical right parties getting into government, securing cabinet portfolios and remaining part of the coalition [...] is not hampered by their extremism on the socio-cultural dimension" since their presence is especially dependent "on their ideological position on the economic register"35. In Schnose's view, this is due to the fact that RRPs "place high

\footnotetext{
30 Ibid.

31 Ibid.

32 Björn Fryklund, "Populism - Changes over Time and Space: A Comparative and Retrospective Analysis of Populist Parties in the Nordic Countries from 1965 to 2012", in Right-Wing Populism in Europe. Politics and Discourse, ed. Ruth Wodak, Majid KhosravNik, and Brigitte Mral (London and New York: Bloomsbury Academic 2013), 268.

33 Ibid.

34 Ibid.

35 Viktorya Schnose, "Mainstreaming the Radical Right", Arts \& Sciences Electronic Theses and Dissertations,

894 ,

2016,

ix,
} 
importance on the socio-cultural dimension and low value on the economic [one]", and therefore, this enables them "to be more flexible in finding compromise with the rest of the coalition partners" 36 .

Furthermore, it is important to note that these "elevated breakthroughs" - that go beyond the electoral contests and which refer to the point where these parties are entrusted with various types of public office - would not be possible without the acquiescence, or even in some case, the acknowledgement and outright approval received from the mainstream centrist parties. This had been possible because at a more general level, we have witnessed a radicalization current encroaching on the center that is reflected in the public discourse. Radical right tropes - be they concerned with immigration, security or safeguarding the nation - are no longer the sole prerogative of the Right being used successfully by also sorts of parties.

The key, as we have noted, is not to break the decorum since it will backfire, draw unwanted attention or make one the object of public scorn whereas it is less likely that the public would react as emphatically if a controversial screed is toned down and dressed up into more palatable clothes. At the very least the racist barks and nationalist wails put one guard, a warning that trouble is brewing, a storm is coming, but the dog whistles, on the other hand, are deceitful, they fool one into a false sense of normalcy and contentment. They create an environment where it becomes hard to believe that things are not what they seem, that words are being weaponized for crude and intolerant reasons as they take advantage of one's inadvertent weaknesses, biases and prejudices. What better moment to speculate and exploit one's shortcomings than during a crisis?

\section{Act 3: The Script}

In the following section, we use the 2015 refugee crisis as a backdrop for our dog whistle-based analysis. It is important to note that the aim of the present study is exploratory in nature and as such it was not

https:/ / openscholarship.wustl.edu/cgi/viewcontent.cgi?article=1895\&context=art_sci_etds 36 Ibid. 
designed to develop a comprehensive taxonomy. The main interest was to identify whether there are instances where the Nordic RRPs are moderating their rhetorical stances especially when confronted with what they would perceive as a foreign "threat" that they have to deal with directly. In subsidiary, the analysis also looks at whether the centrist parties have operated with such a rhetoric. For the Nordic region with its strong welfare systems, the refugee problem found these states scrambling to find solutions that, as Anniken Hagelund observes, would prevent them from "becoming [the refugees] preferred destionation" ${ }^{37}$. In order to do that, the states needed to be unappealing, forestalling entry and imposing strict conditions for those seeking welfare.

In a study from 2018, published by the Migration Policy Institute, titled "The Growth of the Radical Right in Nordic Countries: Observations from the Past 20 Years", Widfelt identifies three factors that have contributed to the success of the RRPs in the Nordic states:

1) "a party platform that addresses salient issues in a way that appeals to a broad audience and avoids overtly extreme or racist proposals";

2) "party discipline and an ability to avoid egregious public scandals";

3) "party leadership that has good communication skills, is politically savvy [meaning it is] (able to cooperate and win favor with other parties), and is pragmatic ([is] able to compromise to achieve goals)" ${ }^{\prime 38}$.

For the purpose of the present study, we are interested in the first trait and specifically in the part concerning the avoidance of "extreme or racist proposals". One way in which these parties try to distance themselves more or less successfully from promoting outright racist appeals, is by resorting to dog whistles. The recurrent coded appeals relate primarily to security and welfare. In terms of welfare, they take the shape of welfare chauvinism, which refers to a "system of social protection [only] for those

\footnotetext{
37 Anniken Hagelund, "After the refugee crisis: public discourse and policy change in Denmark, Norway and Sweden", Comparative Migration Studies 8, article number 13, (2020): 1-2, https://doi.org/10.1186/s40878-019-0169-8.

38 Anders, "The Growth of the Radical Right in Nordic Countries", 1-2.
} 
who belong to the ethnically defined community and who have contributed to it"39.

The 2015 refugee crisis was one of those moments that tests the limits of the institutional order, that reveals the shortcomings, and uncovers the discursive dead-ends. The crisis is a good example to assess where the dog whistle stops and the dog scream begins ${ }^{40}$. In this sense, we will look at several instances that exemplify the type of multivocal communication we have introduced in this article and contrast them with the overt appeals and in one case, even with a textbook exemplification of what a hate speech looks like.

In Denmark, Kristian Thulesen Dahl, the Danish People Party's leader, invokes a dog whistle of the economic variety when stating that:

“The refugees are asylum-shopping. They are travelling through peaceful countries in order to get to the place where they can obtain the best material goods. It's infuriating" ${ }^{\prime 11}$.

At a public policy level, the party's position was not set in stone, switching - from one week to another - from a hardline position rooted in the idea that no refugees should be allowed in Denmark to a more malleable one, touting mollifying words like "national compromise" and acknowledging that the country was faced with "maybe the biggest overall crisis since World War 2" ${ }^{42}$. Dahl's statement above will be counterbalanced by the following mollifying appeal:

"If we were ensured that we are only helping refugees with

\footnotetext{
${ }^{39}$ Herbert Kitschelt in collaboration with A.J. McGann, “The contemporary radical right: an interpretative and explanatory framework", in The Populist Radical Right. A Reader, ed. Cas Mudde (Oxon and New York: Routledge, 2017), 368.

40 Paraphrase from another article. See: Luiza-Maria Filimon, "From the Dog Whistle to the Dog Scream: The Republican Party's (Ab)Use of Discriminatory Speech in Electoral Campaigns and Party Politics", The Romanian Journal of Society and Politics 11, no. 2 (2016): 25-48.

41 Malcolm Brabant, "Denmark takes action against refugees", Deutsche Welle, 09.09.2015, https://www.dw.com/en/denmark-takes-action-against-refugees/a-18702816.

42 ***, "Danish People's Party: Refugees to Greenland", The Local, 17.09.2015, https://www.thelocal.dk/20150917/danish-peoples-party-send-refugees-to-greenland.
} 
temporary protection in Denmark, then we would be much more positive towards more coming to Denmark. That is something we are ready to accept" ${ }^{\prime 4}$.

In the elections held in June of that year - during the height of the crisis - Danish People's Party placed second behind the Social Democrats. Moreover, the difference between the two was barely above five percentage points $(26.3 \% \text { vs. } 21.1 \%)^{44}$. The party was not part of the government, but just like during the previous three occasions, it provided parliamentarian support to the Venstre-led cabinet. Though the Danish People's Party won more votes, it had more leverage over the policy from the outside - a strategy that had proven successful time and time again especially when it came to a pet peeve like immigration ${ }^{45}$.

Furthermore, at the intersection between the radical right becoming mainstream and the center veering into radical positions, we find the position of the Danish government. In a move that could be described as induced by "radical osmosis", the government published advertisements in Lebanese media that sought to depict Denmark as a bad country for refugees. Among the information included in these adverts, there were mentions about new regulations on immigration and welfare that significantly reduced social benefits:

"The social benefits for newcomer refugees will be reduced by up to 50 per cent" or references to the fact "that foreign nationals granted a temporary residence permit will not have the right to have their family brought to Denmark during the first year" 46 .

\footnotetext{
43 Ibid.

44 Folketinget (The Danish Parliament), "Results of the Danish Election", 19.06.2015, https://www.thedanishparliament.dk/en/news/2015/06/2015_eng_results.

45 For an overview of the Danish People's Party's practices, see: Luiza-Maria Filimon, "Beneficiaries of the Second Order Election Model: Radical Right Parties in the European Parliament", Europolity - Continuity and Change in European Governance 9, no. 2 (2015): 193223.

46 Adam Taylor, “Denmark puts ad in Lebanese newspapers: Dear refugees, don't come here", The Washington Post, 07.09.2015, https://www.washingtonpost.com/news/worldviews/wp/2015/09/07/denmark-placesan-advertisement-in-lebanese-newspapers-dear-refugees-dont-come-here/.
} 
Another initiative of the Danish government sought to seize the assets of asylum-seekers in order to compensate for the costs they incurred. Inger Stoejberg, the Integration Minister, argued that "police should be allowed to seize valuables to make them pay for housing, healthcare and some education" 47 . On the upside, objects "with a sentimental value" like wedding rings were not going to be repossessed. The proposal was backed by both Venstre and the Danish People's Party ${ }^{48}$. While the Justice Minister attempted to justify the initiative by referring to an instance where "a hypothetical asylum seeker arriv[ed] with a suitcase full of diamonds", the Danish People's Party considered that even "items of smaller value should also be impounded" ${ }^{49}$. In defending the law, Stoejberg pointed out to the fact that:
“Europe currently receives a very high number of refugees. [...] Denmark does take a share. However, [too many refugees] put pressure on the Danish society and make it more difficult to ensure a successful integration of those who come to Denmark"50.

Over in Norway, we identified a series of racist screeds that ultimately had a negative impact on the Progress Party's tough stance on immigration especially when considering the dimensions of the crisis and the plight of the refugees. The calls for towns and cities to reject the refugees were met with a cold shoulder. Compare Dahl's statement about asylum-shopping cited above with the racist messaging made by a member of the parliament from the Progress Party. Christian Tybring-Gjedde proposed that the UN should "buy or lease a Greek island and set up an

\footnotetext{
$47 * * *$, Denmark plan to seize migrants' assets draws protests", BBC News, 18.12.2015, https://www.bbc.com/news/world-europe-35134150.

48 Ibid.

${ }^{49}$ Rick Noack, "Denmark wants to seize jewelry and cash from refugees", The Washington Post, 18.12.2015, https://www.washingtonpost.com/news/worldviews/wp/2015/12/17/denmark-wantsto-seize-jewelry-from-refugees/.

50 Ibid.
} 
asylum center there" ${ }^{\prime 51}$. Aside from that, the refugees that were already in Europe were also supposed to be sent to this island in order for their asylum applications to be processed ${ }^{52}$. This attitude would prove to be a liability for the party's chances in that year's local elections: while it remained the third largest party, it failed to garner even $10 \%$ of the votes.

At a later date, the Justice Minister Sylvi Listhaug from the Progress Party was forced to quit after posting a photo on Facebook depicting menacing looking people wearing military fatigues and black scarves while flaunting weapons. Across the photo, a message stated that: "Labor thinks terrorists' rights are more important than the nation's security"53 (see Figure 2). Notably, during Listhaug's tenure, the number of asylum seekers dropped from 30.000 to 2000 over the course of two years (2015-2017). Viewed as potential successor for the leadership of the party, Listhaug was not at the first offense though in this second instance, the tone was significantly mellower. In another Facebook post from 2016 that attracted 20.000 likes, Listhaug - at that time, the Integration Minister - stated that:

"I think those who come to Norway need to adapt to our society. Here we eat pork, drink alcohol and show our face. You must abide by the values, laws and regulations that are in Norway when you come here" ${ }^{\prime \prime 4}$.

Unlike the post that triggered a backlash and led to Listhaug's resignation, the message above is tone-downed, it speaks about integration, about the need to conform to the host nation's way of being. It appears reasonable. Moreover, while the second sentence is ethnically targeted, it is not extremist in its framing. This is because it is not formulated in an

51 Nina Berglund, "Progress Party losing on refugees", NewsinEnglish.no, 10.09.2015, https:// www.newsinenglish.no/2015/09/10/progress-party-losing-on-refugees/.

52 Ibid.

53 Gwladys Fouche, "Norwegian political storm evokes Trump and Breivik", Reuters, 12.03.2018, $\quad$ https://www.reuters.com/article/us-norway-politics-breivik/norwegianpolitical-storm-evokes-trump-and-breivik-idUSKCN1GO1R3.

$54 * * *$, Muslims call for Norway minister to resign after pork post", The Local, 20.10.2016, https:// www.thelocal.no/20161020/muslims-call-for-norway-minister-to-resign-after-porkpost. 
imperative manner or as an obligation, the meaning is rather exculpatory, the implication being that just because there is this Muslim presence in the country - no matter how small - Norway, as a society should not stop doing those things that might appear offensive or inconsiderate to such people. After all, laws banning the veil are not a rarity where the European Union is concerned. In the same year, over in Germany, Angela Merkel stated that veils covering the full face should be prohibited "whenever it is legally possible" ${ }^{\prime 55}$. The dog whistle masks an exclusionary intent, by invoking the need for the newcomers to seek assimilation, therefore signaling to their target audience that the repercussions for this "foreign" presence are not going unnoticed and the people admitted will not be left to their own devices.

$55 * * *$ "The Islamic veil across Europe", BBC News, 31.05.2018, https://www.bbc.com/news/world-europe-13038095. 


\section{Sylvi Listhaug}

i går kl. 08:35 · $\mathrm{G}$

\section{Vi vil inndra pass og statsborgerskap til fremmedkrigere og terrorister raskt og effektivt! Det vil Arbeiderpartiet stemme ned. I kampen mot terror kan vi ikke sitte og toe hendene våre!}

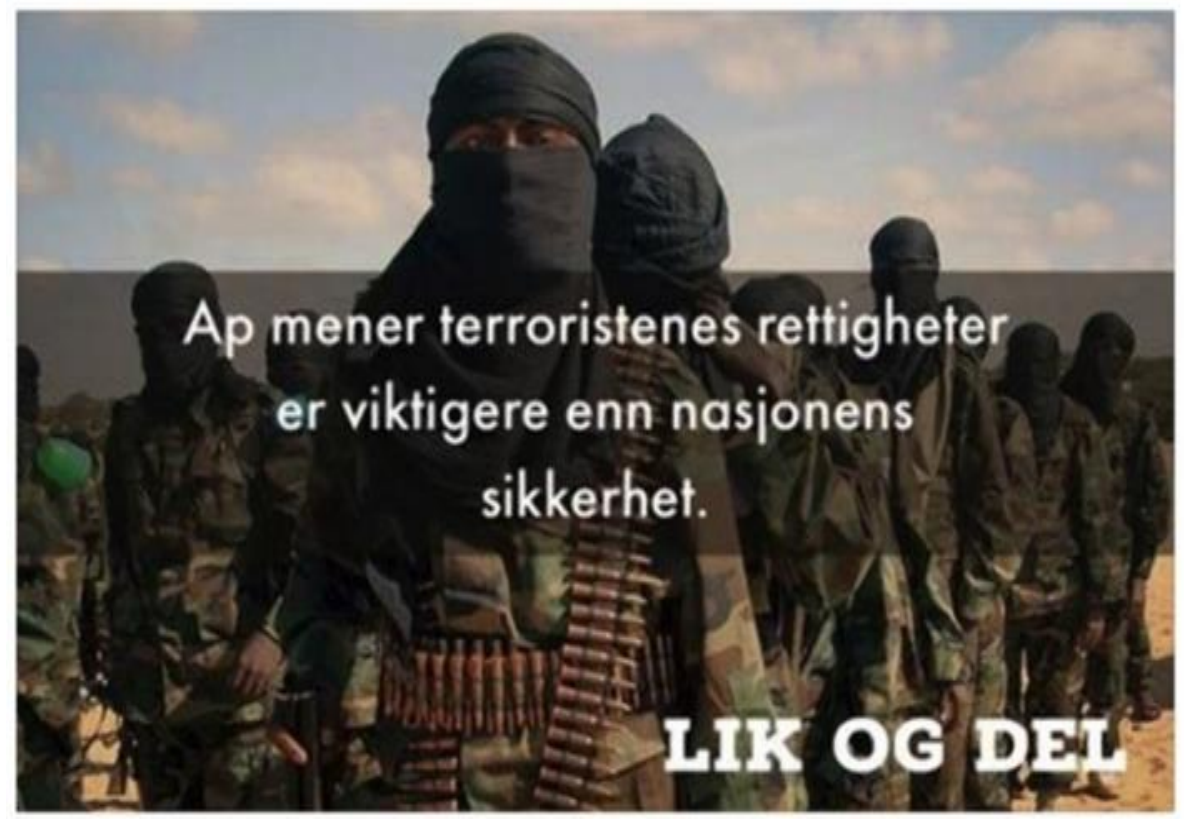

Figure 2: Sylvi Listhaug's Original Facebook Post (since deleted)

Source: Michael Barrett, “Norway's justice minister causes anger with 'rights of terrorists' Facebook post aimed at rivals", The Local, 13.03.2018, https://www.thelocal.no/20180313/norways-justice-minister-causescontroversy-with-terrorists-facebook-post-aimed-at-rivals.

In Finland, we find instances of both extremist screeds as well as coded appeals. In the first case, we identified the Facebook post made by Finns Party's Member of Parliament, Olli Immonen on July 24, 2015, at the height of the refugee crisis:

"I'm dreaming of a strong, brave nation that will defeat this nightmare called multiculturalism. This ugly bubble that our enemies live in, will soon enough burst into a million little pieces. [...]. I have strong belief in my fellow fighters. We will fight until the end for our 
homeland and one true Finnish nation. The victory will be ours" 56 .

By comparison, the leader of the Finns, Jussi Halla-Aho, who is known for his own past controversial statements, stated that:

\begin{abstract}
"We want a society in which as many people as possible are able to look after themselves and take responsibility for their own wellbeing, in addition to taking care of those who are unable to do this on their own. This is economically feasible only if our customer base is limited to our own nation [emphasis added]"57.
\end{abstract}

On one hand, Halla-Aho's moderate stance echoes in effect the thesis of a prosperity radicalism where the left-wing benefits resulted from the welfare state are co-opted by radical groups but only as far the local population is concerned - "our own nation". On the other hand, we also find a trace of "pulling yourself up by your bootstraps" rhetoric and the "personal responsibility" dog whistle ${ }^{58}$. Those seeking entry should demonstrate that they are capable of taking care of themselves and not become a burden which in the given case is a demand hard to comply with since the people affected are refugees who by definition are in need of protection and require access to public assistance. In Halla-Aho's statement, the refugees do not factor in as people "who are unable to do this on their own" - that privilege is only reserved to the natives.

In Sweden, Jimmie Åkesson, the leader of the Sweden Democrats, opted for technicalities in reacting to the refugee crisis, arguing that:

\footnotetext{
56 Ishaan Tharoor, "A politician in Finland declared war on multiculturalism. This is how his country responded.", The Washington Post, 31.07.2015, https://www.washingtonpost.com/news/worldviews/wp/2015/07/31/a-politician-infinland-declared-war-on-multiculturalism-this-is-how-his-country-responded/. $57 * * *$, "Finns Party seeks to "take care of only Finnish citizens"”, Yle, 01.09.2018, https://yle.fi/uutiset/osasto/news/finns_party_seeks_to_take_care_of_only_finnish_citize $\underline{\text { ns } / 10382954}$.

58 Andreas Wiedermann and Tess Wise, "The Dog-Whislte Politics of Personal Responsibility, Credit, and the American Welfare State", Working Paper, 17.07.2020, https://ssrn.com/abstract=3579128 or http://dx.doi.org/10.2139/ssrn.3579128.
} 
"Sweden cannot take them. The absolute majority, if not all, of those seeking asylum in Sweden don't have Sweden as their first safe country. They come from Germany and they come from Denmark. And they came to those countries from other countries". "At some time you have to cherish the principle of first asylum," he continued. "[...] It should not be particularly difficult to tell people that, unfortunately, you will not enter our country because it is full" [emphasis added] ${ }^{59}$.

For comparison, the Employment Minister, Ylva Johansson, a Social Democrat, talked about:

"islands where social problems have become concentrated and unemployment, bad school results and other social problems amplify each other", adding that while these issues may not be related to the country's capacity to take refugees in, they speak about the "failures of integration" 60 .

Both instances are exclusionary in nature though of the two, the statement made by Johansson is the one that fully embodies the dog whistle, checking all the boxes of a coded framing: it mentions unemployment, poor education, and social problems (which is another way of referring to the criminality issue). Everything is neatly encapsulated in the idea of "islands marked by the failure of integration". In the selected paragraph, Åkesson does not invoke the problems that could be associated with these foreigners and like his Finish counterpart, employs a common sense approach across economic considerations: there is only so much Sweden can do as a country and the country's priority should first and foremost be the Swedes. In this case, we can see how mainstream political language adopts tropes from the radical bag and how unlike the radicals, the person stating

59 ***, “Åkesson: 'Stay away, refugees, Sweden is full', The Local, 17.10.2015, https:// www.thelocal.se/20151017/kesson-stay-away-refugees-sweden-is-full.

60 Simon Johnson and Johan Sennero, "REFILE - In Nordics, many refugees encounter a paradise lost", Reuters, 02.09.2015, https://www.reuters.com/article/europe-migrantssweden/refile-in-nordics-many-refugees-encounter-a-paradise-lost-

idUSL5N1161QO20150902. 
it is a policy-maker, a member of the Cabinet who can - just like in the Danish case - operationalize this exclusionary rhetoric into policy without attracting too much if any criticism at all precisely because of who is making the statement.

These brief examples illustrate that whenever the policy-makers veer into the extreme, the public opinion recoils, the statements are disavowed, and there is a national, even an international uproar, but if kept on the down-low and in a clinical register, the reactions are more muted. As noted in the newspaper articles cited, this kind of response is reflected in the media: a traditional racist approach that speaks about the various "ills" and "shortcomings" of the Other will be acknowledge and penalized whereas the more sterile variety, divorced of a racialized animus will not receive a similar pushback. The refugee crisis brought to the fore both a radical register as well as a coded one that appealed to the welfare of the nations and of the people's within. Due to the magnitude of the crisis and the way it encompassed the European continent from one end to another, two things happened: an inevitable radical backlash threw Europe into a wall-building frenzy, which was then was doubled by a discursive realignment. For every appeal towards the fellow man, for tolerance, inclusion and co-existence, there was also an opposite reaction that speculated the fears, that fermented the grudges, that cultivated all those insidious feelings that people are capable of during times of intense duress. Where the policy outcomes were concerned, the methods varied, but at the end of the day, the Nordic countries pivoted towards what Hagelund describes as a "restrictive direction" 61 .

\section{Conclusions}

In the early '90s, there was this assumption that the end of the Cold War also put an end to the old demons. After all, the Good side had prevailed. We had arrived at the end of history and ahead of us laid the balmy days of progress, tolerance and synergetic multiculturality. A

61 Hagelund, "After the refugee crisis", 2. For a detailed analysis on the effects over the integration policies, see: Vilde Hernes, "Cross-national convergence in times of crisis? Integration policies before, during and after the refugee crisis", West European Politics 41, no. 6 (2018): 1305-1329. 
veritable Tower of Babel in reverse, only this time an incensed higher power would no longer smite the people and scatter them to the four corners of the world. A perfect narrative all wrapped in a neat bow. But if there is anything that perfection does best, that's to breed hubris. Racism, intolerance, discrimination did not go down gently into the night, instead people found new ways for them to self-actualize, to become better versions of themselves, to become deeply intertwined within our societies, skulking in our midst. For the unassuming public, it is precisely this weakness that is being speculated when dog whistles begin to shape the discourse. The recourse to dog whistles in the Nordic case, enabled these parties to whitewash the more fringe stances even though for the time being, they are continue to be defined by their radical past and some of their present excesses tend to reconfirm that nothing is worn better than some old, familiar clothes.

This being said, there is also an electoral dilemma that such parties are forced to navigate since depending on what type of appeals they engage with, they risk alienating voters. Too overt and one loses the more moderate segments of one's base, too covert and one's hardline supporters who were there since the beginning might abandon them in favor of even more radical options. More importantly, we have to take into account the fact that the coded appeals employed by these parties will also be used by other parties on the spectrum. This should give one pause because if the RRPs incur losses for having their platforms highjacked by the moderate options like in the Danish case, then instead of combating these messages and finding ways to desocialize the racist reflexes present in society, we are faced with a capitulation in front of these radical impulses which are now further enabled and legitimated.

The RRPs' use of dog whistles can be framed as an attempt to attract new voters and expand the voting pool especially when considering that they are trying to put behind them their problematic background, but their presence in the political messaging of the more moderate political options is indicative of the fact that more and more, large segments of the electorate are increasingly resonating with certain radical positions. The dog whistles are therefore a warning signal and it would be advised to grow attuned to 
them in order to be able to counteract the ways in which they shape views, change minds, and impact policy.

\section{References:}

***. "Norway party quits government in 'jihadist-wife' row". BBC News, 20.01.2020. https://www.bbc.com/news/world-europe-51174550

***. "Mette Frederiksen: The new face of the Danish Social Democratic model". The Local, 04.06.2019. https://www.thelocal.dk/20190604/mette-frederiksen-the-new-faceof-the-danish-social-democratic-model.

***. "Finns Party seeks to 'take care of only Finnish citizens'". Yle, 01.09.2018.

https://yle.fi/uutiset/osasto/news/finns_party_seeks_to_take_care_of _only_finnish_citizens/10382954.

***. "The Islamic veil across Europe". BBC News, 31.05.2018. https://www.bbc.com/news/world-europe-13038095.

***. "Finland's populist party has cracked in two". The Economist, 14.06.2017. https://www.economist.com/europe/2017/06/14/finlandspopulist-party-has-cracked-in-two.

***. Muslims call for Norway minister to resign after pork post". The Local, 20.10.2016. https://www.thelocal.no/20161020/muslims-call-fornorway-minister-to-resign-after-pork-post.

***. Denmark plan to seize migrants' assets draws protests". BBC News, 18.12.2015. https://www.bbc.com/news/world-europe-35134150.

***. “Åkesson: 'Stay away, refugees, Sweden is full”. The Local, 17.10.2015. https://www.thelocal.se/20151017/kesson-stay-away-refugeessweden-is-full.

***. "Danish People's Party: Refugees to Greenland". The Local, 17.09.2015. https://www.thelocal.dk/20150917/danish-peoples-party-sendrefugees-to-greenland.

Akkerman, Tjitske, Sarah L de Lange, and Matthijs Roodujin. "Inclusion and mainstreaming? Radical right-wing populist parties in the new millennium". In Radical Right-Wing Populist Parties in Western 
Europe. Into the Mainstream?, edited by Tjitske Akkerman, Sarah L de Lange, and Matthijs Roodujin, 1-28. Oxon and New York: Routledge, 2016.

Albertson, Bethany L. “Dog whistle Politics: Multivocal Communication and Religious Appeals". Political Behavior 41, 1117 (December 2019). https://doi.org/10.1007/s11109-019-09568-3.

Barrett, Michael. "Danish People's Party braces itself for tough election night". The Local, 04.06.2019. https://www.thelocal.dk/20190604/danish-peoples-party-bracesitself-for-tough-election-night

Barrett, Michael. "Norway's justice minister causes anger with 'rights of terrorists' Facebook post aimed at rivals". The Local, 13.03.2018. https://www.thelocal.no/20180313/norways-justice-minister-causescontroversy-with-terrorists-facebook-post-aimed-at-rivals.

Berglund, Nina, "Progress Party losing on refugees". NewsinEnglish.no, 10.09.2015. https://www.newsinenglish.no/2015/09/10/progressparty-losing-on-refugees/.

Bhat, Prashanth, and Ofra Klein. "Covert Hate Speech: White Nationalists and Dog Whistle Communication on Twitter". In Twitter, the Public Sphere, and the Chaos of Online Deliberation, edited by Gwen Bouvier and Judith E. Rosenbaum, 151-172. Cham, Switzerland: Palgrave Macmillan, 2020.

Brabant, Malcolm. "Denmark takes action against refugees". Deutsche Welle, 09.09.2015. https://www.dw.com/en/denmark-takes-action-againstrefugees/a-18702816.

Folketinget (The Danish Parliament). "Results of the Danish Election". 19.06.2015.

https:/www.thedanishparliament.dk/en/news/2015/06/2015_eng_re sults.

Fouche, Gwladys. "Norwegian political storm evokes Trump and Breivik". Reuters, 12.03.2018. https://www.reuters.com/article/us-norwaypolitics-breivik/norwegian-political-storm-evokes-trump-andbreivik-idUSKCN1GO1R3. 
Fryklund, Björn. "Populism - Changes over Time and Space: A Comparative and Retrospective Analysis of Populist Parties in the Nordic Countries from 1965 to 2012". In Right-Wing Populism in Europe. Politics and Discourse, edited by Ruth Wodak, Majid KhosravNik, and Brigitte Mral, 267-276. London and New York: Bloomsbury Academic 2013

Grossman, Sara. “Blog: Revisiting 'Dog Whistle Politics'”. Othering \& Belonging Institute. https://belonging.berkeley.edu/blog-revisitingdog whistle-politics.

Hagelund, Anniken. "After the refugee crisis: public discourse and policy change in Denmark, Norway and Sweden". Comparative Migration Studies 8, article number 13, (2020): 1-17. https://doi.org/10.1186/s40878-019-0169-8

Haney-López, Ian. Dog Whistle Politics: How Coded Racial Appeals Have Reinvented Racism and Wrecked the Middle Class. Oxford: Oxford University Press, 2014.

Henley, Jon. “Denmark's centre-left set to win election with antiimmigration shift". The Guardian, 04.06.2019. https://www.theguardian.com/world/2019/jun/04/denmark-centreleft-predicted-win-election-social-democrats-anti-immigrationpolicies.

Ivănescu, Mihaela, and Luiza-Maria Filimon. "Mainstream Fringes or Fringe Mainstream? An Assessment of Radical Right (Re) Alignments in the European Parliament after the 2014 and 2019 Elections". European Review, 2020. https://doi.org/10.1017/S1062798720000976.

Johnson, Simon, and Johan Sennero. "REFILE - In Nordics, many refugees encounter a paradise lost". Reuters, 02.09.2015. https://www.reuters.com/article/europe-migrants-sweden/refile-innordics-many-refugees-encounter-a-paradise-lostidUSL5N1161QO20150902.

Kitschelt, Herbert, and A.J. McGann. “The contemporary radical right: an interpretative and explanatory framework". In The Populist Radical 
Right. A Reader, edited by Cas Mudde, 352-386. Oxon and New York: Routledge, 2017.

McDonnell, Duncan, and Annika Werner. “Respectable radicals: why some radical right parties in the European Parliament forsake policy congruence". Journal of European Public Policy 25, no. 5 (2018): 747763. https://doi.org/10.1080/13501763.2017.1298659.

Niklasson, Elisabeth, and Herdis Hølleland. "The Scandinavian far-right and the new politicisation of heritage". Journal of Social Archaeology 18, no. 2 (June 2018): 121-148. https://doi.org/10.1177/1469605318757340.

Noack, Rick. "Denmark wants to seize jewelry and cash from refugees". The Washington Post, 18.12.2015. https://www.washingtonpost.com/news/worldviews/wp/2015/12/17 /denmark-wants-to-seize-jewelry-from-refugees/.

Olasov, Ian. "Offensive political dog whistles: you know them when you hear them. Or do you?". Vox, 07.11.2016. https://www.vox.com/thebig-idea/2016/11/7/13549154/dog whistles-campaign-racism.

Orange, Richard. "Mette Frederiksen: the anti-immigration left leader set to win power in Denmark". The Guardian, 11.05.2019. https://www.theguardian.com/world/2019/may/11/denmarkelection-matte-frederiksen-leftwing-immigration.

Perlstein, Rick. "Exclusive: Lee Atwater's Infamous 1981 Interview on the Southern Strategy". The Nation, 13.11.2012. https://www.thenation.com/article/archive/exclusive-lee-atwatersinfamous-1981-interview-southern-strategy/.

Saul, Jennifer. "Dogwhistles, Political Manipulation, and Philosophy of Language". In New Work on Speech Acts, edited by Daniel Fogal, Daniel W. Harris, and Matt Moss, 360-383. Oxford: Oxford University Press, 2018.

Saul, Jennifer. "Donald Trump, Racial Figleaves, and the Breadth of Bigotry". Huffington Post, 21.01.2016. https://www.huffpost.com/entry/donald-trump-racialfigle_b_9033224?guccounter=1. 
Schnose, Viktorya. "Mainstreaming the Radical Right". Arts \& Sciences Electronic Theses and Dissertations, 894, 2016. https://openscholarship.wustl.edu/cgi/viewcontent.cgi?article=1895 \&context=art_sci_etds.

Taylor, Adam. "Denmark puts ad in Lebanese newspapers: Dear refugees, don't come here". The Washington Post, 07.09.2015. https://www.washingtonpost.com/news/worldviews/wp/2015/09/07 /denmark-places-an-advertisement-in-lebanese-newspapers-dearrefugees-dont-come-here/.

Tharoor, Ishaan. "A politician in Finland declared war on multiculturalism. This is how his country responded". The Washington Post, 31.07.2015.

https://www.washingtonpost.com/news/worldviews/wp/2015/07/31 /a-politician-in-finland-declared-war-on-multiculturalism-this-ishow-his-country-responded/.

Widfeldt, Anders."The Radical Right in the Nordic Countries". In The Oxford Handbook of the Radical Right, edited by Jens Rydgren, 545564. Oxford: Oxford University Press, 2018.

Widfeldt, Anders. "The Growth of the Radical Right in Nordic Countries: Observations from the Past 20 Years". Migration Policy Institute, Washington DC, June 2018. www.migrationpolicy.org

Witten, Kimberly. "Dogwhistle Politics: the New Pitch of an Old Narrative". San Francisco University, Spring 2008. https://www.academia.edu/42929858/Dogwhistle_Politics_the_New _Pitch_of_an_Old_Narrative. 